\title{
CHROMOSOME BEHAVIOUR IN SOME TROPICAL PLANTS
}

\author{
N. W. SIMMONDS \\ Botany Department, Imperial College of Tropical Agriculture, Trinidad, B.W.I. \\ Received 20.iv.53

\section{INTRODUCTION}

IN this paper the chromosome numbers and other cytological features of certain tropical plants are reported. Some of the plants are of economic importance; others, especially in the Commelinaceæ and Scitaminex, are not. Frequent reference has been made to Darlington and Janaki Ammal (1945, abbreviated to D. \& J., 1945) and to Tjio (1945). Sampson (1930) is the principal authority for nomenclature.

Root tips were taken from cuttings (RTC) or from seedlings (RTS) ; they were normally fixed in Craf or ${ }_{2} \mathrm{BE}$ and stained in crystal violet but a few were successfully treated by the oxyquinolineorcein method of Tjio and Levan (1950). For pollen mother cells, aceto-carmine following fixation in acetic alcohol was normally used. Propionic-carmine without prefixation was good in some cases.

\section{THE OCCURRENCE OF TRIPLOIDY}

Two of the plants examined are triploid ; significantly, both are vegetatively-propagated monocotyledons (like some hyacinths, tulips and bananas). One, Xanthosoma helleborifolium, is a tuberous weed and the other, Costus sericeus, a seed-sterile rhizomatous cultivated plant.

TABLE 1

Meiosis in Costus sericeus

\begin{tabular}{|c|c|c|c|c|}
\hline \multirow{3}{*}{ Configurations } & $\left\{\begin{array}{c|c}\text { I III } \\
\text { 9 II }\end{array}\right.$ & $\begin{array}{l}\text { 8 II } \\
\text { 8 I I }\end{array}$ & $\begin{array}{c}\text { 8 II } \\
\text { I I I }\end{array}$ & $\begin{array}{c}\text { I III } \\
\text { I II I }\end{array}$ \\
\hline Cells & I3 & 3 & I & I \\
\hline
\end{tabular}

The chromosome number of Costus sericeus was $2 n=3 x=27$. Pairing at meiosis was reduced (table I). Anaphases were correspondingly irregular. This is suggestive of allotriploidy resultant from hybridity between distinct tetraploid and diploid species-AAAA $\times$ BB $\longrightarrow$ AAB. Only a tetraploid has so far been reported (under Costus speciosus-Banerji, 1940; Raghavan and Venkatasubban, 1943). It 
therefore seems likely that this extremely variable and confused species (or, better, species-complex) includes several distinct taxonomic entities and perhaps some hybrids between them. In Trinidad the plant is pollen- and seed-sterile but has considerable powers of spread and persistence by vegetative means; it has thus become well established in many of the damper parts of the island as an escape from cultivation.

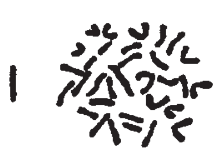

3

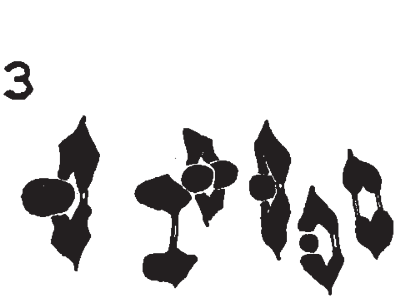

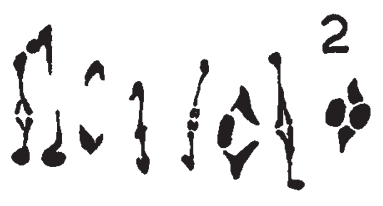

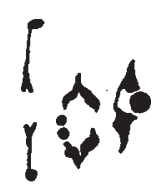

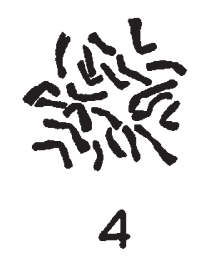

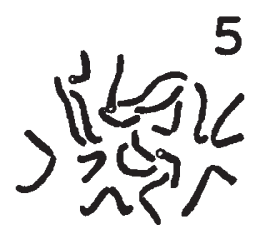

Fig. I.

I. Melicocca bijuga. RTS. $2 n=32 . \times 2100$.

2. Canavalia ensiformis. PMC. $2 n=22$, I I bivalents. $\times 2040$.

3. Sesbania speciosa. PMC. $2 n=12,6$ bivalents. $\times 2040$.

4. Tephrosia candida. RTS. $2 n=22 . \times 1860$.

5. Passiflora laurifolia. RTC. $2 n=18 . \times 2100$.

\section{THE OCCURRENCE OF INTERCHANGE}

In Strelitzia augusta (Strelitziaceæ, $2 n=22$ ) a quadrivalent was present in 96 per cent. of the first metaphases examined (figs. 2-7). It

TABLE 2

Meiosis in Strelitzia augusta

\begin{tabular}{|c|c|c|c|c|c|}
\hline Quadrivalent & \multicolumn{4}{|c|}{ Present } & Absent \\
\hline Configuration & \multicolumn{2}{|c|}{ Chain } & \multicolumn{2}{|c|}{ Ring } & \\
\hline Orientation & Convergent & Parallel & Convergent & Not & \\
\hline Cells & 5 & 2 & I & I 6 & I \\
\hline
\end{tabular}

was convergently oriented in only about 24 per cent. of cells and thus gave rise to considerable gametic sterility. Five out of 30 first anaphases showed numerical non-disjunction. Of a sample of 500 pollen grains, 34 per cent. were morphologically sound, in fair agreement 
with the expected 26 per cent. calculated from first metaphase data (table 2).

The mean numbers of chiasmata per arm were $0.9 \mathrm{I}$ in both bivalents and quadrivalents. Thus, in Strelitzia with a relatively high chiasma frequency, association-in-four is virtually always achieved but orientation fails and sterility ensues. In Musa acuminata, by contrast, a related plant with chromosomes of similar size, chiasma frequency is lower (0.75 per arm, Dodds, 1943) and association-infour is rare. Even though multivalents are usually convergent, sterility ensues though from quite a different cause (Dodds and Simmonds, I948).

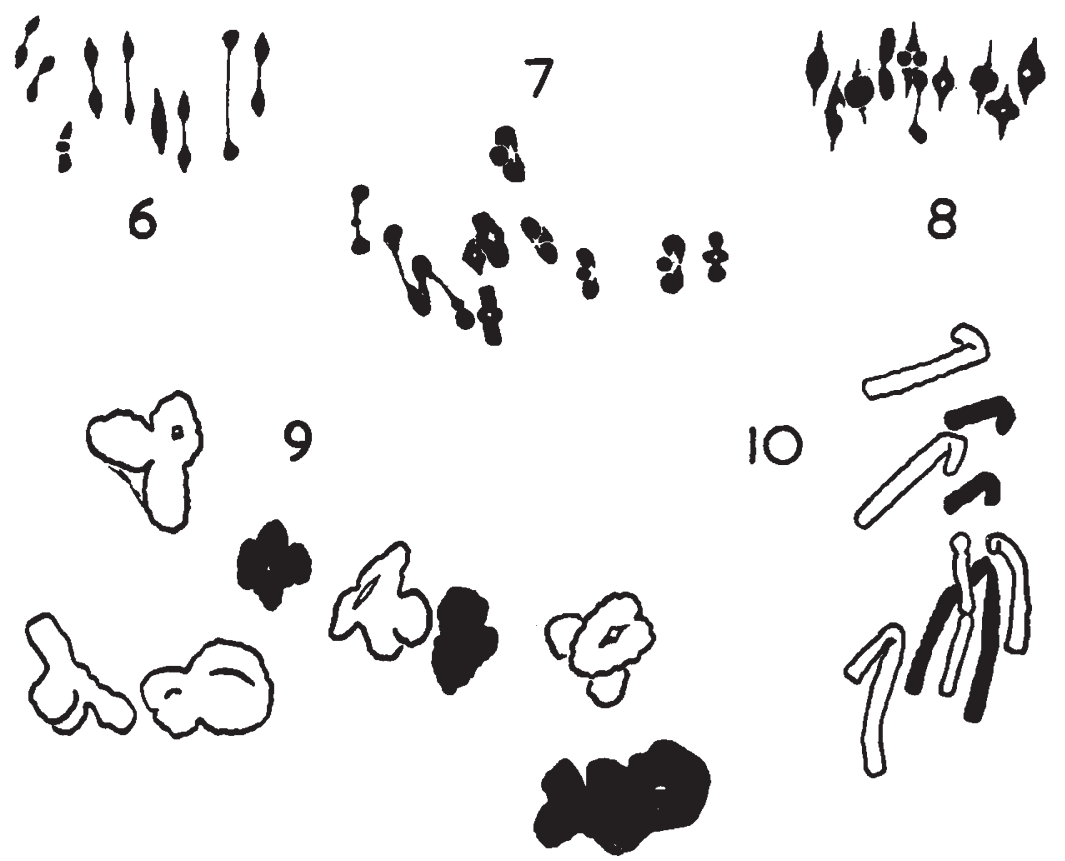

Fig. 2.

6. Carica papaya. PMC. $2 n=18,9$ bivalents. $\times 2040$.

7. Strelitzia augusta. PMC. $2 n=22,9$ bivalents and one convergent chain quadrivalent. $\times 2040$.

8. Aneilema nudiflorum. PMC. $2 n=20$, 10 bivalents. $\times 1620$.

9. Campelia zanonia. PMC. $2 n=16,8$ bivalents, the largest and two smaller pairs shown in black, the others in outline. $\times 1620$.

10. Campelia zanonia. PMC. $2 n=16$, second anaphase to show chromosome shapes. $\times 1620$.

In two members of the Commelinacex, the failure of occurrence of interchange is significant. Neither Campelia zanonia nor Zebrina pendula gave evidence of interchange hybridity though it had been recorded by previous investigators (Anderson and Sax, I936; and Darlington, 1929, 1937 respectively). Evidently, structural hybridity is variable in these species, floating adaptively in the population as it does in Campanula. 


\section{LIST \\ New counts and counts differing from those prevously recorded are marked with asterisks}

ANNONACE E. Annona squamosa L. Sugar apple. RTS. $2 n=14$. Annona muricata L. Soursop. RTS. $2 n=14$.

BIXACEE. Bixa orellana $*$ L. Anatto. RTS. $2 n=16$, differing from the $2 n=14$ of Janaki Ammal (D. \& J., 1945).

TILIACE E. Corchorus capsularis L. Jute. RTS. $2 n=\mathbf{I} 4$.

STERGULIACEÆ. Theobroma cacao L., Th. bicolor H.B.K., Th. angustifolia * Moc. \& Sess. ex DG. Herrania purpurea * Pitt., H. albiflora * Goudot. Cacao, wild and cultivated. RTS, RTG. $2 n=20$ in all cases. The first two agree with Carletto (1946).

RUTACE E. Citrus aurantiifolia (Christm.) Swingle. Lime. PMC in acetocarmine after acetic-alcohol fixation. $2 n=18,9$ bivalents formed regularly.

C. aurantium L. Sour orange. RTS. $2 n=18$.

MELIACE E. Cedrela odorata * L. West Indian or cigar-box cedar. RTC. $2 n=50-52$, the chromosomes very small.

SAPINDACE E. Melicocca bijuga $*$ L. Genip. RTS. $2 n=32$. (fig. 1-I).

ANACARDIACE $E$. Anacardium occidentale L. Cashew. RTS. $2 n=c a$ 40 ( $c f$. $2 n=42$ of Janaki Ammal in D. \& J., 1945).

Mangifera indica L. Mango. RTS. $2 n=c a 40$, tentatively confirming Janaki Ammal (in D. \& J., I945) and Mukherjee (1950).

Spondias mombin * L. Hogplum. RTS. $2 n=32$.

LEGUMINOSÆ. Canavalia ensiformis DC. Jack, Sword or Horse bean. RTS. $2 n=22$. PMC in aceto-carmine after fixation in acetic alcohol showed regular formation of I I bivalents whose structure could sometimes be resolved with remarkable clarity despite their comparatively small size (fig. I-2).

Canavalia plagiosperma * Piper. RTS. $2 n=22$.

Cyamopsis psoraloides DG. Cluster bean. RTS. $2 n=14$.

Erythrina poeppigiana * (Walp.) O.F. Cook. Anauca immortelle. PMC in aceto-carmine. $2 n=4^{2}, 2$ I bivalents regularly formed.

Erythrina velutina Willd. PMC in aceto-carmine. $2 n=42,21$ bivalents regularly formed. Material taken from an ornamental tree introduced to Trinidad from Venezuela by A. H. G. Alston. Atchison (1947) also found $2 n=42$.

Gliricidia sepium * (Jacq.) Steud. Nicaraguan cocoa shade, Madre de Cacao. PMC in aceto-carmine. $2 n=22$, I I bivalents regularly formed. This result differs from that of Atchison (1951) who found $2 n=20$.

Indigofera endecaphylla $*$ Jacq. PMC in aceto-carmine. $2 n=32,16$ small bivalents regularly formed.

Phaseolus aureus Roxb. Mung, green gram. RTS. $2 n=22$.

Phaseolus mungo L. Urd, wooly pyrol, black gram. RTS. $2 n=22$.

Pithecellobium saman Benth. Saman, Rain tree. RTS. $2 n=26$, as found by Atchison (1951).

Pueraria hirsuta * Scheid. ( $P$. thunbergiana Benth.) Kudzu. PMC in acetocarmine. $2 n=22$, meiosis normal.

Saraca indica L. PMC in aceto-carmine. $2 n=24$, meiosis normal.

Sesbania speciosa * Taubert. PMC in aceto-carmine. $2 n=12$, meiosis virtually normal with six large bivalents (fig. I-3). Rare chromatid bridges without fragments were seen at first anaphase-telophase.

Tephrosia candida $*$ DG. RTS. $2 n=22$ (fig. I-4).

MYRTACEE. Eugenia malaccensis L. Pomerac. RTS. $2 n=22$.

Eugenia uniflora $*$ L. Surinam cherry. RTS. $2 n=22$.

COMBRETACEE. Terminalia catappa $*$ L. Almond. RTS. $2 n=24$. 
PASSIFLORACE E. Passiflora laurifolia L. Belle apple, water lemon. RTC. $2 n=\mathrm{I} 8$ (fig. I-5) as found by Storey (1950).

CARICACE $Æ$. Carica papaya L. Papaw, papaya. PMC in aceto-carmine. $2 n=\mathrm{r} 8$. Of first metaphases, 19 were regular with 9 small ring or chain bivalents (fig. 2-6) ; one contained 8 bivalents and 2 univalents. Of first anaphases, 29 were normal with 9-9 disjunction; one showed numerical non-disjunction; and another contained a bridge but no visible fragment.

RUBIACE E. Coffea robusta Linden, C. excelsa A. Chev., C. liberica Bull ex Hiern. Coffee. RTS. $2 n=22$ in each case.

BIGNONIACE $Æ$. Bignonia unguis-cati * L. Catsclaw. RTC. $2 n=40$.

Callichlamys latifolia * (L. G. Rich.) K. Schum. RTC. $2 n=40$.

Crescentia cujete* L. Calabash. RTS. $2 n=40$.

Crescentia (Engallena) latifolia* Mill. RTS. $2 n=40$.

Jacaranda carulea $*$ Juss. RTC. $2 n=36$.

Kigelia pinnata DC. Sausage tree. RTS. $2 n=40$.

Paragonia pyramidata * (Rich.) Bur. RTC. $2 n=40$.

Phryganocydia corymbosa * (Vent.) Bur. RTC. $2 n=40$.

Pseudocalymma macrocarpum * (Donn. Sm.) Sandw. RTC. $2 n=38$.

Tabebuia pallida* Miers. White cedar. RTS. $2 n=40$.

Tabebuia serratifolia * (Vahl) Nichols. Yellow poui. RTS. $2 n=40$.

Parmentiera cereifera * Seeman. Candle tree. RTS. $2 n=40$.

All species in this family except in Crescentia were counted by K. Shepherd.

NYCTAGINACE $Æ$. Bougainvillea spp. PMC in aceto-carmine. $2 n=34$ in several cases ; irregularities of pairing and disjunction (bridge formation) indicated hybridity in some varieties, in accord with taxonomic expectation and in agreement with Wilson (1947). There is great need for a thorough cytotaxonomic study of the group which is technically quite favourable for cytological work.

POLYGONACE E. Antigonon leptopus * Hook. \& Arn. Corallita. RTC. $2 n=42-$ 44, probably the latter, differing from 40 and $4^{8}$ previously recorded (D. \& J., 1945).

MYRISTICACE E. Myristica fragrans * Houtt. Nutmeg. RTS. $2 n=42$.

LAURACE E. Persea americana Mill. Avocado or Alligator pear. RTS. $2 n=24$.

PROTEACE $\approx$. Grevillea robusta A. Cunn. Silky oak. RTS. $2 n=20$.

EUPHORBIACE E. Manihot utilissima Pohl. Cassava, tapioca. RTC. $2 n=36$.

Ricinus communis L. Castor oil. RTS and PMC in aceto-carmine. $2 n=20$, meiosis regular.

ORCHIDACE Æ. Vanilla planifolia Andr. Vanilla. RTC. $2 n=32$.

STRELITZIACE $Æ$. Heliconia psittacorum L. Material from Piarco, Trinidad. PMC in aceto-carmine. $2 n=24$, meiosis virtually regular. 35 cells had I 2 bivalents, two had II bivalents and 2 univalents. There was an average of 5.5 ring bivalents per nucleus and 6.5 rods.

Heliconia bihai (L.) L. Material from Arima-Blanchisseuse Road, Trinidad. $2 n=24$, meiosis regular. I 3 cells had 12 bivalents each with an average of 7.8 rings per cell, perhaps a little higher than in $H$. psittacorum.

Ravenala madagascariensis Gmel. PMC in aceto-carmine. $2 n=22$, meiosis regular.

Strelitzia augusta Thunb. PMC in aceto-carmine. $2 n=22$. An interchange heterozygote (see section 3 above).

ZINGIBERACE E. Costus cylindricus (Plum.) Jacq. Material from the ArimaBlanchisseuse Rd., Trinidad. PMC in aceto-carmine. $2 n=18$, meiosis regular.

Costus friederichsenii * O. G. Peters. Material from the Arima-Blanchisseuse Rd., Trinidad. PMC in aceto-carmine. $2 n=18$, meiosis regular.

Costus niveo-purpureus* Jacq. Material from Diego Martin, Trinidad. PMC in aceto-carmine. $2 n=18$, meiosis regular, though rare failure of pairing in one bivalent was noticed. 


\section{ZINGIBERACE $\approx-$ continued.}

Costus sericeus* Blume (C. speciosus (Koenig) Sm. var. argyrophyllus Wall. ex Baker). Widely naturalized in Trinidad. PMC in aceto-carmine. $2 n=3 x=27$, a triploid (see Section 2, above).

GANNACE $Æ$. Canna edulis Ker-Gawl. Queensland arrowroot. RTC. $2 n=18$.

MARANTACEÆ. Maranta arundinacea L. West Indian arrowroot. RTC. $2 n=48$.

DIOSCOREACE $Æ$. Dioscorea alata $*$ L. White Lisbon yam. RTC. $2 n=40$. Smith (1937) has recorded $2 n=c a .81$.

COMMELINACEÆ. Tradescantia elongata* G. F. W. Mey. Material from the Arima-Blanchisseuse Rd., Trinidad. PMC in aceto-carmine. $2 n=c a 5^{\circ}$. Meiosis was extremely irregular with numerous laggards and bridges in both divisions ; the plant was both male-and female-sterile.

Tradescantia geniculata * Jacq. Material from El Tucuche, Trinidad. PMC in aceto-carmine. $2 n=48$, meiosis regular, except for bridge and fragment at first anaphase $(2 / 38$ cells). Pollen was good and fruits were abundantly set. Anderson and Sax (1936) recorded $2 n=32$; thus the Trinidad plant is probably a hexaploid based on $x=8$.

Commelina diffusa * Burm. fil. sensu Merrill. Material from the Botany Department, I.C.T.A., Trinidad. RTC. $2 n=30$. A new chromosome number for the genus Commelina.

Commelina elegans* H.B.K. Material from the Botany Department, I.C.T.A. RTC. $2 n=c a 52$.

Aneilema nudiflorum* (L.) Wall. Material from the I.C.T.A., Trinidad. PMC in aceto-carmine. $2 n=20$, meiosis regular (fig. 2-8). Pollen good and seeds freely set. The basic number of the genus is presumably 10 , not 20 as indicated in D. \& J. (1945).

Campelia zanonia H.B.K. Material from el Cerro del Aripo, Trinidad. PMC in aceto-carmine. $2 n=16$, meiosis regular (figs. 2-9 and 2-10), except for an occasional failure of pairing in a bivalent at metaphase. Pollen is abundant and seed freely set.

Zebrina pendula Schnitz. RTC and PMC in aceto-carmine. This plant is common in Trinidad (especially in cacao estates), but flowers have been seen only thrice and even then very few in number. Twelve bivalents were regularly found at first metaphase ; about I per cent. of first anaphasetelophase stages showed a bridge with or without fragment.

PALMÆ. Roystonea oleracea * (Jacq.) O. F. Cook. Cabbage palm. RTS. $2 n=36$.

ARACE $Æ$. Anthurium andreanum Lind. Anthurium lily. RTC. $2 n=30$.

Colocasia esculenta Schott. Dasheen, eddoe, etc. RTC. $2 n=28$.

Philodendron giganteum * Schott. Material from Maracas Bay, Trinidad. RTS. $2 n=30$.

Xanthosoma helleborifolium * (Jacq.) Schott. Fowl foot bhaji (Trinidad). Material from the Botany Department, I.C.T.A., Trinidad, a weed. RTC. $2 n=39$. Presumably a triploid. It is propagated by its persistent tubers.

Typhonium trilobatum * (L.) Schott. RTC. $2 n=26$.

Caladium bicolor * (Ait.) Vent. Material from the Botany Department, I.C.T.A., Trinidad, a weed. RTG. $2 n=30$. Seed sterile and propagated by its persistent tubers.

GRAMINEÆ. Pennisetum purpureum Schum. Elephant grass, etc. RTC. $2 n=28$, in three distinct clones.

Tripsacum australe Cutler and Anderson. PMG in aceto-carmine. $2 n=36$, 18 bivalents in each of ro diakineses; but, rarely, univalents were seen ir other cells and a bridge with (probable) fragment at first anaphase. Pollen was abundant and seed was regularly set. The present count confirms that of Graner and Addison (1944). 
GRAMINE E-continued.

Tripsacum lalifolium Hitchc. Wild on hillside, Tunapuna, Trinidad. PMC in aceto-carmine. $2 n=72$, meiosis rather irregular with about 6 univalents per cell at diakinesis and 4.5 lagging at metaphase.

Polytoca macrophylla Benth. Material from Fiji collected by Dr K. S. Dodds and subsequently determined at Kew. PMC in aceto-carmine. $2 n=40$, meiosis regular.

\section{SUMMARY}

Chromosome numbers are reported for 87 species of tropical plants. There are included 38 new counts and 5 that differ from the published figures; information about meiosis is given for 28 species. Most of the plants studied are of economic importance. Some information is given on the occurrence of triploidy and interchange hybridity and upon the comparative cytology of the Scitamineæ and Commelinaceæ.

Acknowledgments. - I am indebted to Dr K. S. Dodds for help; to Mr N. Y. Sandwith for taxonomic determination of specimens of Scitaminex and Commelinaceæ; and to Mr K. Shepherd for certain counts in Bignoniacex.

\section{REFERENCES}

ANDERSON, E., AND SAX, K. I936. A cytological monograph of the American species of Tradescantia. Bot. Gaz., 97, 433-76.

ATchison, E. 1947. Studies in the Leguminosæ I. Chromosome numbers in Erythrina L. Amer. F. Bot., 34, 407-14.

Atchison, E. 1951. Studies in the Leguminosæ. VI. Chromosome numbers among tropical woody species. Amer. F. Bot., $38,538-46$.

BANERJI, t. A. I940. A contribution to the life history of Costus speciosus Smith. F. Ind. bot. Soc., 19, 181-196.

CARLETto, G. M. 1946. O numero de cromosomios em cacaueiros. Bol. Tec. Inst. Cacau Bahia, 6, 31-42. (Abstract in Hort. Abstr., 17, 412.)

DARLINGTON, G. D. 1929. Chromosome behaviour and structural hybridity in the Tradescantix I. F. Genet., 21, 207-286.

DARLINGTON, G. D. 1937. Chromosome behaviour and structural hybridity in the Tradescantix II. F. Genet., 35, 259-28o.

DARlington, C. D., AND JANAKI AMmal, E. K. 1945. Chromosome Atlas of Cultivated Plants. London.

DoDDs, K. s. 1943. Genetical and cytological studies of Musa V. Certain edible diploids. F. Genet., 45, I I $3-138$.

DODDs, K. S., AND SIMmONDS, N. w. 1948. Sterility and parthenocarpy in diploid hybrids of Musa. Heredity, 2, 101-1 17.

GRANER, E. A., AND ADDisON, G. 1944. Meiose em Tripsacum australe Cutler e Anderson. Sep. 9, An. Esc. Super Agric. " "Luiz de Queiroz," Univ. Sao Paulo, pp. 213-224.

MUKHERJEE, S. K. 1950. Cytological investigation of the Mango (Mangifera indica L.) and the allied Indian species. Proc. nat. Inst. Sci. India. 16, 287-303.

RAGHAVAN, T. S., AND venkatasubban, K. R. 1943. Cytological studies in the family Zingiberacex with special reference to chromosome number and cytotaxonomy. Proc. Ind. Acad. Sci., 17, 1 18-1 34 . 
SAMPSON, H. G. 1930. Cultivated crop plants of the British Empire and AngloEgyptian Sudan (Tropical and Subtropical). Kew Bull. misc. Inf. Add. Ser., I2, pp. 25I. London.

SMIтH, в. w. 1937. Notes on the cytology and distribution of the Dioscoreaceæ. Bull. Torr. bot. Club, 64, 189-197.

STOREY, W. B. 1950. Chromosome numbers of some species of Passiflora occurring in Hawaii. Pacific Science, 4, 37-42.

тJIо, J. H. 1948. The somatic chromosomes of some tropical plants. Hereditas, Lund, 34, I 35-1 46 .

TJ10, J. H., AND LEVAN, A. 1950. The use of oxyquinoline in chromosome analysis, An. Est. Exp. de Aula Dei, 2, 21-64.

wILson, G. B. 1947. Mejosis in Bougainvillea. Nature, Lond., 160, 121 